Cellular Physiology and Biochemistry
Cell Physiol Biochem 2014;33:681-691 DOI: $10.1159 / 000358644$

Published online: March 06, 2014

Accepted: January 24, 2014
(C) 2014 S. Karger AG, Basel

www.karger.com/cpb

$1421-9778 / 14 / 0333-0681 \$ 39.50 / 0$
Karger Open access

681

Retracted Paper

This is an Open Access article licensed under the terms of the Creative Commons AttributionNonCommercial 3.0 Unported license (CC BY-NC) (www.karger.com/OA-license), applicable to

\title{
Estradiol Modulates the Expression Pattern of Myosin Heavy Chain Subtypes via an ER $\alpha$-Mediated Pathway in Muscle-Derived Tissues and Satellite Cells
}

Tao Guo a,d Wenjia Liu ${ }^{b, d}$ Anna Konermannc,d Zexu Gua Meng Cao ${ }^{a}$ Yin Ding ${ }^{a}$

${ }^{a}$ Department of Orthodontics, School of Stomatology, the Fourth Military Medical University, ${ }^{\text {b Research }}$ and Development Center for Tissue Engineering, the Fourth Military Medical University, Xi'an, Shaanxi, People's Republic of China; ' Department of Orthodontics, Medical Faculty, University of Bonn, Bonn,

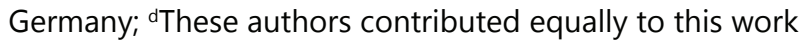

